\title{
A Look into Russia's Post-Cold War Concerns and Future Implications in the Late 1990s Political Scene
}

\author{
Frank Fuller1,2,3,4, Donald Bradt' ${ }^{2}$, Howard C. Smith ${ }^{5}$ \\ ${ }^{1}$ Department of Political Science, Villanova University, Villanova, USA \\ ${ }^{2}$ Department of Political Science, Lincoln University of Pennsylvania, Chester County, USA \\ ${ }^{3}$ Department of Political Science, Rowan University, Glassboro, USA \\ ${ }^{4}$ Department of Political Science, Philadelphia University, Philadelphia, USA \\ ${ }^{5}$ Department of Political Science, University of Arkansas, Pine Bluff, USA \\ Email: frankiefuller@gmail.com
}

Received 7 July 2014; revised 9 August 2014; accepted 20 August 2014

Copyright (C) 2014 by authors and Scientific Research Publishing Inc.

This work is licensed under the Creative Commons Attribution International License (CC BY). http://creativecommons.org/licenses/by/4.0/

cC) (7) Open Access

\begin{abstract}
This article discusses the major implications for Russia's future immediately after the Cold War and primarily the period up into the late 1990s and beyond, when Russia was in turmoil politically and economically. It's economy that had recently recovered to a point that Yeltsin had left and Putin was beginning to solidify his power. Predictions were made as to what Russia's future looked like and how it appeared to be very similar to forecast its actions in the present day. The nationalistic sentiment felt in the late 1990s carried over to the current situation in Russia's involvement in what could have been or where it would go years later. Overall, the future for Russia at the time looked positive, though the nation was uncertain what type of leader would emerge from the situation immediately following the Cold War Period and after an economic crisis.
\end{abstract}

Keywords

Russia, Economic Crisis, Nationalism

\section{Introduction}

Russia as a nation has always been a very nationalistic country, and its policies in the future will revolve around this; though it will gradually become a more democratic country and expand into global markets, it will never lose its fervor for that nationalism. Another factor that comes into play when discussing Russian politics is the 
general Orthodoxy of the country and its influence on the people in deciding whom to establish their alliances with. In the future, Russia will ally itself with many nations that surround it and exercise these relations whenever any conflicts arise. Its military capabilities, though declining, will depend more on negotiations and on other countries' involvement, such as an organization similar to the United Nations, but also a world market, such as stated above in discussing the economy. The factors other than military ones will come into play gradually, as Russia will begin to understand that economic strength is more efficient in the long run, and in any case, it would be a waste of time and money for Russia to try to keep up its military and nuclear capability as it has in the past; in fact, the only situation that would call for any sort of military buildup would be if there were some kind of national emergency where any or all of its alliances would be rendered helpless except Russia, or a country desperately needed Russia's help. Increasingly, though, as the future progresses, despite whatever may happen, Russia will continually reduce its military and become more of an economic nation.

Russia's economy is not getting much better than it has in the past, but it is gradually adjusting little by little to capitalism, and it is certainly more efficient than under the old Soviet system. There is still a lot of political corruption in the country, though, such as the Russian mafia and the violence that they impose on the rest of the country and its small businesses. There are many Russian conglomerates and large industries that are not allowing the others to compete in the marketplace, and the tax system is not fair. The business elites and the politicians are corrupt, and one of the main reasons why there is this elitism and the economy continues to be stagnant is because the bureaucrats and other government officials accept bribes. Therefore, the reform that is supposed to occur does not come through because of the blockage by these various forms of bribery and the reshaping of the policies towards what the rich businessmen desire it to be, as explained here:

A small group of businessmen enriched themselves and then corrupted many of Russia's politicians and officials. They have all conspired to stymie liberal economic reforms, which would stimulate growth and help the overall population, because reform threatens their domination. Russia suffers not from too free a market but from corruption thriving on the excessive regulations erected by a large and pervasive state. Russia's tragedy is that reformers never had enough power to overrule these avaricious interests. Joel Hellman of the European Bank for Reconstruction and Development characterizes the problem of partial reform as "winners take all” (Aslund, 1999).

Only if this system changes somehow and the political system becomes more stable will there be any hope for some sort of growth, and if the business elite reduce their stranglehold (Aslund, 1999).

The country is actually growing at a very, very slow rate, but it still needs more technological work. The main industries include machinery, forestry, textiles, food, and construction materials. These are fields in which income and profit can be generated into an economy, but for Russia to be truly efficient and compete with the rest of the world, some measures need to be taken to upgrade technology and the industries along with them. Once they make a little more, they can start building towards these goals of more advanced manufacturing businesses such as computers, automobiles, and perhaps petroleum-based products. Of course, they were badly in need of strong leadership to get anywhere in the 1990s, since Yeltsin could not seem to keep his head on straight or even stay sober enough to set forth any legitimate policy and bring the people together to make a difference for all of them, and Putin seems to want to stay in power indefinitely.

\section{Unity and Ethnic Concerns}

Unity among the ethnic groups would be one of the most partial means by which to bring the Russian people together, for making a country stable requires peace among its people. Then, working as one for their nation, they could cooperate, increase their domestic capital, fix their economy, and look forward to a future that could expand globally and challenge the other nations of the world They are a fiercely nationalistic people, and this can be dangerous for them also, for if they let nationalism dominate, other minority groups will feel dejected and unwelcome as a part of the Russian nation, and a leader as dangerous as the sinister Vladimir Zhirinovsky could gain political prominence and threaten the legitimate leadership, and its repercussions can be seen here.

Russian nationalists of the extreme right claim that patriotism, nationalism and chauvinism are synonyms. In their hearts and politics they differentiate little between patriotism and nationalism. As they see it, nationalism is the most sacred inspiration in life; only through belonging to a nation (or the folk) does the life of the individual gain spiritual meaning; differences between nations are fundamental, and commit- 
ment to one's nation transcends all other obligations (Lacqueur, 1992).

In may well be that Boris Yeltsin and the reformers with whom he surrounded himself until his recent lurch to the Right knowingly promoted privatization in order to raise insuperable obstacles to a restoration of Communism (1999).

Currently, the situation with the Chechens can be seen as a model example of how Russia deals with its minorities, and the policy with which it handles this situation will dictate future Russian policy. It seems that they must find a way to find a way to address them instead of harboring a hard-line policy of bombing these people and destroying them outright. The Russians have a perfectly good reason to fear terrorism from militant separatists amongst this minority group, since there have been terrorist attacks that have caused the Russian people to retaliate out of fear of a situation that can go out of control, but they are not quite handling it in a way that looks toward a reasonable promise for peace, as explained thus, "Radio Liberty, the US broadcast service, quoted witnesses who said the soldiers opened fire on the white-flagged convoy of seven automobiles and a bus Friday morning as the vehicles paused at a military checkpoint south of the Chechen capital, Grozny” (Wines, 1999). They first have to understand exactly what it is that is going on, and they should at least send in a mediator to negotiate and to offer to have an open forum to settle it once and for all. Why does Russia not let them have their own country? Bombing a people only makes them more infuriated, and attempting to destroy them utterly does not make them go away. It is true that there are valuable resources that Russia wishes to hold on to in Chechnya, but there is a deeper reason behind all of this, and it ultimately comes down to religion, mixed in with a little bit of nationalism, as explained here:

Who belongs here? Only ethnic Russians who also belong to the Orthodox Church. Catholics, Muslims, Protestants, or Jews can be Russian subjects, they can be tolerated and given freedom of religious practice, they even can be given certain civic rights. But since "Holy Russia" is meaningless for them, they cannot be true Russians. Some enlightened soul s on the right are willing to make concessions; certain individuals of non-Russian blood can become true Russian patriots and identify themselves thoroughly through a great effort and their willingness to sacrifice for the motherland. But these will always be a very few. Others, more extreme, will not make exceptions whatsoever: A Jew baptized is a thief pardoned, as a Russian proverb says (Lacqueur, 1992).

The Russian people are mostly Eastern Orthodox; the Chechens are mostly Muslim. To understand the political disputes that arise, a little history behind Russia's evolution and its politics needs to be given.

\section{Post-Cold War Issues}

The Cold War ending brought about a change in global politics. Global politics was no longer divided between the United States and Russia, the two superpowers. Civilization groups started to form, with core states and their member states: "Countries tend to bandwagon with countries of similar culture and to balance against countries with which they lack cultural community" (Huntington, 1997). Also, it can be said that global "power is obsolete” (1997). Concerning the Orthodox civilization, Russia is the center.

It has taken quite some time for the Western countries to come together. Also, for Russia to materialize, it has not taken a short time, especially with Georgia and the Ukraine, which are Orthodox countries. Two factors can make some countries resistant to adhere to the core state influences, which are historical relationships and power balance considerations. As a certain civilizational consciousness increasingly gathers strength, the resistant countries will gradually give in to and join the core state. Europe and Christianity end at a certain point, and then Islam and Orthodoxy commence there. The "Great Divide" replaces the "Iron Curtain", and it is between those who got Christianity from Rome and those who obtained its influence through Constantinople.

Western civilization has a security organization in NATO. NATO's main function was to stop Russia from getting military and political control back in Central Europe. Russia is not amused at the possibility of NATO expanding into Eastern Europe, and this concept makes stronger political forces that are nationalist and against the West in Russia.

Russia is an influential power with interests within its region, and the country also has civilizational ambitions, as described here:

Overall Russia is creating a bloc with an Orthodox heartland under its leadership and a surrounding buffer 
of relatively weak Islamic states which it will in varying degrees dominate and from which it will attempt to exclude the influence of other powers. Russia also expects the world to accept and approve this system (Huntington, 1997).

Peter the Great assumed that modernization went together with Westernization in the seventeenth century, but he only formed a divided country instead. The next two centuries brought up the debate of whether to Europeanize or get rid of these stimuli and bring back the true "soul" of Russia (Lacqueur, 1992). The concept of fault line conflicts deal with an "us" versus "them" mentality. In this, political leaders broaden and intensify their appeals to the loyalty of both ethnicity and religion, and the consciousness of civilization is reinforced in conjunction with other identities. A "hate dynamic" starts to materialize that is comparable to the "security dilemma", in which mutual fears, suspicion, and abhorrence feed on one another. These are called "identity wars". The political issues that lie within, who is going to control a certain territory and which people on defined terms, keep coming up and do not bring the parties to any agreement (Huntington, 1997). Fault line violence can only be stopped for a certain amount of time, but it does not actually end forever. These fault line wars are sporadic, and these conflicts are endless. These wars do not come to a conclusion by individuals who have no interest, groups, or organizations but by parties, minor and tertiary, who have come to the aid of their allies in support of their brethren and have the ability and potential to come up with agreements with their counterparts, on a certain note, and to encourage their brothers to come to terms with these agreements, on another note. These less significant groups who rally have more varied interests than the primary ones, and they normally do not wish to be turned into first-level combatants and therefore try to keep the war under some sort of control. They tend to have an off-again on-again quality because they contain roots in unfathomable fault line conflicts that involve sustained hostile relations between groups of varying civilizations. The conflicts, then, come from a geographical proximity, different religions and cultures, social structures that are separated, and memories rooted in history of both societies (Huntington, 1997).

Russia is and has been declining militarily since the end of the Cold War. In fact, while Russia ranks third behind the United States and the People's Republic of China in military spending (Stockholm International Peace Research Institute, 2013), its force needs to undergo further modernization and its military personnel better training. In addition, a country's military power is ultimately undergirded by economic power. This military decline, is due, in part, to the growing necessity and the importance of maintaining a stable economy that is able to benefit from free trade and the global market. In fact, Russia does have the six largest GDP in the world after the US, China, India, Japan, and Germany (CIA, 2014). On the other hand, Russian growth in GDP has been diminishing. Russian GDP growth in 2011 was 4.3 percent, 20123.4 percent, and in 2013 it dropped to 1.3 percent. Competition among nations forces Russia to obligate itself to try keeping up with and focusing on how domestic politics can expand and reach out instead of trying to keep itself isolated, and these issues call for a lesser focus on the military strength and in the ability to negotiate and prevent the further expansion of more countries gaining nuclear capability. The countries that have this capability, therefore, work together to settle disputes and merely use nuclear weapons now to intimidate and influence policy and gain power. Capitalism has lent its hand to the country, and there is no turning back once a country has experienced the benefits of a free market. In perhaps twenty or thirty years, Russia will begin to witness some tangible benefits of capitalism, and it might then be able to compete with the other nations on trade and in importing and exporting its goods.

\section{Nationalism and Territorial Issues}

There still exists a possibility, though, that Russia may become too involved in its nationalistic sentiment and its longing for the glory days of the past. This is apparent in its recent occupation of the Crimean peninsula and the push into Eastern Ukraine amidst the claims of historical territory or simply protecting the interests of the ethnic Russians there (Myers, 2014). While it may have made some strategic sense for Putin to grab off the Crimea peninsula during the continuing crisis between Russia and the Ukraine, the fomenting of "separatist" pro-Russian warfare within Ukraine does not serve a strategic purpose for Russia. So far, the "separatists" have not achieved their aim. This aggression has alienated the West and has led President Obama to increase the level of sanctions against Russia. These further sanctions imposed July 16, 2014 have resulted in a substantial initial shock to Russian financial markets. Moreover, continued conflict in Eastern Ukraine poses acute risks for the region including risks for Russia. If it turns out that the Russian military or the Russian-controlled separatists shot down a Malaysia passenger jet carrying 295 innocent civilians on July 17, 2014, Russia and Putin will have 
suffered a deep blow to their prestige. In essence, even if the future is bright for Russia's economy, it will only continue to have problems, as the view of Russian ultra-nationalists are depicted here:

Russian ultra-nationalists have openly claimed that Russia has a right to appropriate various foreign territories because of its historic domination of those territories. These same groups also justify their support for particular factions in foreign conflicts (such as the Serbs) on other nebulous grounds, such as "Slavic brotherhood." These groups are vocally expansionist and view other nations as being anti-Russian. Their criterion for security decisions seems to be a romanticized version of Russian historical rights. They do not claim that Russia leads the forces of one social class against another; they reject Kozyrev's argument that Russia must join a Western-style international system conceived by the West, and they do not limit Russia's international security considerations to vital interests (Lacqueur, 1997).

The key to their reaching out globally and going in a positive direction is if they avoid conflicts and getting involved in wars; they can gain more of a legitimate economy. They will not have to worry about the military capability they tried to desperately keep during the Cold War because it cost too much anyway and did little for their economy. Russia has many problems because of these factors, such as thousands of nuclear weapons sitting in fields and wasting away. They have neither the money nor the capability to maintain these weapons, which could be dangerous as time passes because of the possibility of nuclear waste and the radioactivity that occurs as a side effect.

Another potential problem that does not seem to breed responsibility is the fact that with all of these nuclear arms lying around, there is a feeling of desperation as to what to do with them, and in order to benefit somewhat from these, the Russians are willing to sell them to the highest bidder. The problem with this is that Russia cares little about who will buy them, as long as the nation gains a profit and takes them out of their hands. Any nation, be it India, Iran, or China, can buy them, and certain nations are only more than happy to stock up on their nuclear arsenals so that they can get rid of their enemies, or at least intimidate them. This is extremely dangerous in that Iran, for example, does not merely intend on intimidating with these, but may actually consider using them; after all, we are but the Great Satan to many fundamentalists as Ahmadinejad or Bin Laden had implied, and getting rid of us would have brought joy to their hearts and allowed them to gain more political prestige (Brusstar, 1994).

\section{Alliances and the UN}

If Russia considers strengthening its alliances, as it will in the future, they will only become more successful and gain potential as a world power. They will be able to form partnerships that can result in successful tradeoffs in the world market, and these will only benefit everyone involved. Some insight into their military capability and the history of the rise and fall of the Cold War needs to be given in order to understand some of this. The United States and the former Soviet Union carved out a competitive rivalry amongst each other that soon became known as the Cold War, which began soon after World War II and ended around the end of the 1980s. The Russians had a desire for power and wished to spread Communism, which they felt was the best form of government, throughout the world, which began to take effect as they slowly invaded many sections of Eastern Europe and various other countries. They had a certain ambition to be a world superpower, like the United States, and they felt a need to appear intimidating, and so they invested in a nuclear arsenal that grew and grew until it caused enough of a threat to the United States to start a race and build its own. The Soviets' desire to be a world superpower also gradually grew into a technology war, and they competed to be first in everything from sending a satellite into space, which the Russians were first to do, to aiming nuclear warheads at strategic locations throughout the United States. Soviet domination brought about the fall of many Eastern European governments, and as this continued to occur, the United States developed a paranoia that spread into the Domino Theory, which discussed the possibility that if one democracy fell, another could also topple, and so based on this assumption, if one country became Communist and it continued to occur, then gradually it could happen throughout the world, and in the end, also to the United States. We feared this Communist threat so much that we were willing to do almost anything to stop its development, which is elaborated on by Paul Nitze, who was the Policy Planning Staff Director under Truman:

To deal with this possibility, Nitze advocated a strengthening of American and West European conventional forces that went well beyond anything Kennan had envisaged; it might even be necessary, he argued, 
to begin to shift economic priorities away from the production of consumer goods and to resort to a certain amount of “propaganda” to accomplish that objective (Nye Jr., 1991).

This same fear also brought about the Bay of Pigs conflict in Cuba, in which we actually believed the threat of nuclear war to be real and took extreme measures to prepare for it, such as having drills in case of a nuclear attack, building bomb shelters, etc.; it is even plausible to say that the Vietnam conflict arose out of this fear (coupled with other economic interests as well).

\section{Military and Nuclear Issues}

The primary reason behind this nuclear arsenal buildup was, in actuality, to intimidate in the case of a perceived threat. We aimed these missiles at key Russian targets in the same way that they aimed them at us, and we were prepared to set them off as soon as we had reason to believe that the Russians had fired on us first. There was always the constant fear that war could have broken out between these two countries, yet it did not. In fact, later on we understood that merely having the weapons allowed us to influence foreign policy and to help us to search for a way to more peacefully deal with these types of situations, in the hope of decreasing the likelihood of such a catastrophic event. We have become aware of the fact that having nuclear weapons brings us to an understanding of what we can do and how destructive we can be. It also teaches us that if we should ever use them, we face an impending doom that would only cause a chain reaction of horrible repercussions. Alliances have been formed around the world to protect each country and to create a special bond between nations. The experience of these Cold War events shows us that these weapons are too risky and should only be brought forth as a last resort, and they teach us valuable lessons. Many of these countries that are involved in any sort of nuclear arms race have, in fact, learned from us and the Cold War situations, and they have generally agreed on a consensus to institute measures to ban most nuclear testing and to limit the production and the distribution of these devastating toys. The existence of nuclear weapons has, as a matter of fact, brought about more world peace. Both the United States and Russia have been able to become more skilled negotiators instead of preventing wars and international conflicts, but especially the United States, and we can apply this knowledge throughout the rest of the world.

In terms of other Russian military maneuvers, their involvement in Kosovo showed us that even putting military troops in a country can cause a little resentment and some unnecessary scuffling. Russia feels a strong loyalty to its allies, and it wished to protect them from being attacked. Russia acted on its ties and obligations to its allies to prevent any further damage to a country within its greater alliance. To further illustrate an earlier point, these alliances are where Russia’s military is heading, and any sort of alliances can only help them. Because of their more recent involvement in treaties and negotiations, they can have more influence by participating more often in world organizations such as NATO or the United Nations to fight common causes and aid developing war-torn countries. These international organizations and the unity of countries of varying backgrounds to assist in many kinds of global situations, one can assume, is the future of world politics.

\section{Future Political Concerns}

Russia is in need of a fairer and more balanced political system to guide the nation, however. Their system is paying off and is becoming more capitalistic, but it needs a strong leader who appeals to the masses and can be quick and adept at handling situations swiftly and efficiently. Yeltsin appeared to have had several problems in carrying out policies and in being consistent or “on the ball”, and his leadership was constantly questioned because of his health concerns. Russia needs and will most definitely find a leader who has a strong voice and can lead his people to a promising future with an international perspective in the near future, though obviously Putin did not satisfy all of these conditions, as he tended to be a strong leader, but tended to have a myopic vision of Russia as an intimidating presence that has leaned towards authoritarianism. In fact, Putin has, as president or prime minister, thoroughly dominated Russian politics for 14 years. Putin accomplished a great deal in the first half of the 2000s having been groomed and then taking over from Boris Yeltsin. During the 1990s, Yeltsin attempted to lead the country through two profound simultaneous transitions in a relatively brief period of time. In addition to the daunting transitions to democracy and capitalism, Yeltsin was burdened by alcoholism and other health issues. Life expectancy for Russians, especially males, plummeted. Mafiyas took over large swaths of property, including the apartments of elderly Russians within the context of a Russian legal system ill-prepared 
to regulated property rights and other fundamental aspects of capitalism. A profound pessimism set in among the Russian people in the decade of the 1990s as rapidly dropping standards of living, crime, and chaos beset the country. On the other hand, when Vladimir Putin became president of Russia on December 31, 1999, he took over a country on the verge of chaos, even anarchy. He was able to restore the Russian people's pride in themselves. He curbed some of the excesses of the more dubious "reforms" under Yeltsin. The economy started to mend, either because of increasing global energy prices or his new leadership or both. Putin stabilized a country with thousands of thermonuclear weapons.

Despite Putin's long-held grip on Russia's political scene, his current term is supposed to end on May 7, 2018. Hence, Russia will have been ruled by one person for some 18 years. He has bullied internal dissent and kept an iron fist on Russian media and political parties. Externally, he invaded Georgia in 2008, enmeshed his country in a long war in the Crimea, pressured Baltic countries in June of 2014, and is implicated in the shooting down of a civilian airliner with 298 people aboard. During his 14 years in power, Putin seems to have lost perspective of the political realities around him. One can only wonder what Mr. Putin's sense of reality will have become by his 18th year in power.

Presently, the system can only call for more positive change, and the political corruption that still runs rampant in Russia is dwindling; the business leaders are realizing more and more that this is happening and that they can do nothing about it, as depicted here:

The transfer of the nation's wealth from the state into private hands is proceeding apace; perhaps as much as three-quarters of the Gross Domestic Product of Russia today emanates from the private sector. This means that the state no longer controls the economy and cannot use it as a weapon of social control. Furthermore, every owner of property has a vested interest in the rule of law to the extent that it serves his advantage; for even if he has obtained his wealth unlawfully, he relies on the law to safeguard it for him. In may well be that Boris Yeltsin and the reformers with whom he surrounded himself until his recent lurch to the Right knowingly promoted privatization in order to raise insuperable obstacles to a restoration of Communism (Pipes, 1996).

This means that the people will ultimately have more power to elect a more democratic system and put into place these politicians who can and will carry out the will of the people.

Currently, Russia's economy is solely linked to Europe and their dependency on it for energy. Russia has become so viable to the world that it has emerged as a global necessity in Europe. What has been the strategy of recent years is to allow Russia a seat among many major Western powers, which often offers incentive to developing their very own economy. The recent embargos on Russia following the 2014 Crimean Crisis on oil and natural gas had such an impact on other European nations that it reflects the new global model of interdependence that is a reflection of Post-Cold War politics (Schoen, 2014). Therefore, present acts of aggression in the Ukraine have mirrored former Soviet Union objectives in Eastern Europe. These actions have been viewed by Western Powers as overly aggressive, causing Russia to lose its seat among major European nations in the G8, but yet still have economic influence in the global world. This kind of position in the global world has the potential of moving Russia into similar positions of Middle Eastern nations that lack governmental stability, but yet has such an enormous economic effect on other nations.

\section{Conclusion}

Russia's future is bright, for it has learned its lessons of the past and can only continue to develop its economy. Its military policy is focused more now on helping resolve international disputes and how to ally itself with other nations in order to gain more political, economic, and social prestige. In this way, it is still able to maintain its national identity and to be a nation proud of its general Orthodoxy, but at the same time, in forming these alliances, it is able to concentrate on the more important aspects of developing its economy and gaining some sort of political stability instead of having to worry so much about outside threats. In essence, its domestic issues become international issues at the same time because of the tie-in with the global market, and everything about its military is strengthened because of the stability and general assurance that the United Nations will hardly become obsolete, due mainly to the fact that much of it is backed by the United States and its all-encompassing and widely influential free-market economy. In conclusion, considering all of these factors coming into play, it is not implausible to think of Russia again becoming a great world power sometime in the near future, perhaps in twenty or thirty years. 


\section{References}

Aslund, A. (1999). Russia’s Collapse. Foreign Affairs, 78, 64-77. http://dx.doi.org/10.2307/20049451

Brusstar, J. H. (1994). Russian Vital Interests and Western Security. Orbits, 607-619.

CIA (2014). The World Fact Book. https://www.cia.gov/library/publications/the-world-factbook/

Huntington, S. (1997). The Clash of Civilizations and the Remaking of World Order. New York: Simon and Schuster Inc. Lacqueur, W. (1992). Russian Nationalism. Foreign Affairs, 103-116.

Myers, S. L. (2014). Putin Engages in Test of Will Over Ukraine. New York Times, 2 March 2014.

http://www.nytimes.com/2014/03/03/world/europe/putin-engages-in-test-of-will-over-ukraine.html?_r=0

Nye Jr., J. S. (1991). Bound to Lead: The Changing Nature of American Power (2nd ed.). New York: Basic Books.

Pipes, R. (1996). Russia’s Past, Russia’s Future. Commentary, 30-38.

Schoen, J. W. (2014). New Sanctions Will Hurt More Russia. NBC News, 30 July 2014.

http://www.nbcnews.com/storyline/ukraine-crisis/new-sanctions-will-hurt-more-russia-n168016

Stockholm International Peace Institute (2013). Global Issues: Social, Political, Economic, and Environmental Issues That Affect Us All. http://www.globalissues.org/article/75/world-military-spending

Wines, M. (1999). Refugees Say Russians Killed 40. New York Times, 5 December 1999. (from The Atlanta Journal-Constitution, 5 Dec. 1999, A3). 
Scientific Research Publishing (SCIRP) is one of the largest Open Access journal publishers. It is currently publishing more than 200 open access, online, peer-reviewed journals covering a wide range of academic disciplines. SCIRP serves the worldwide academic communities and contributes to the progress and application of science with its publication.

Other selected journals from SCIRP are listed as below. Submit your manuscript to us via either submit@scirp.org or Online Submission Portal.
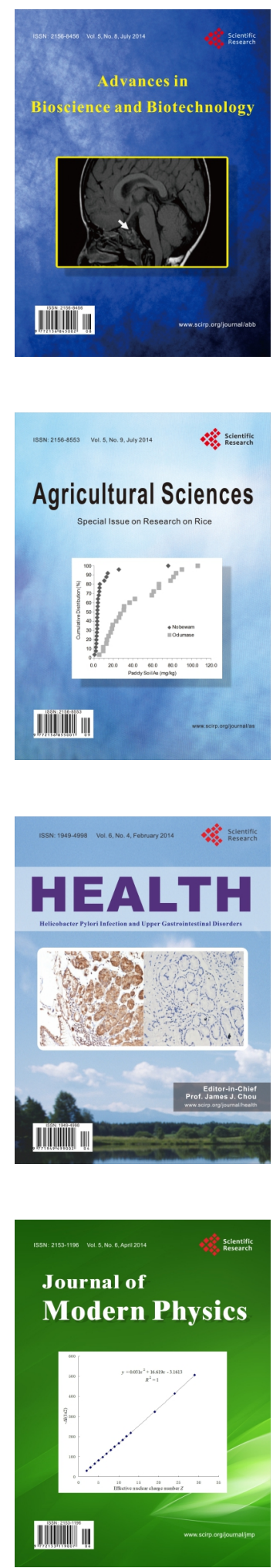
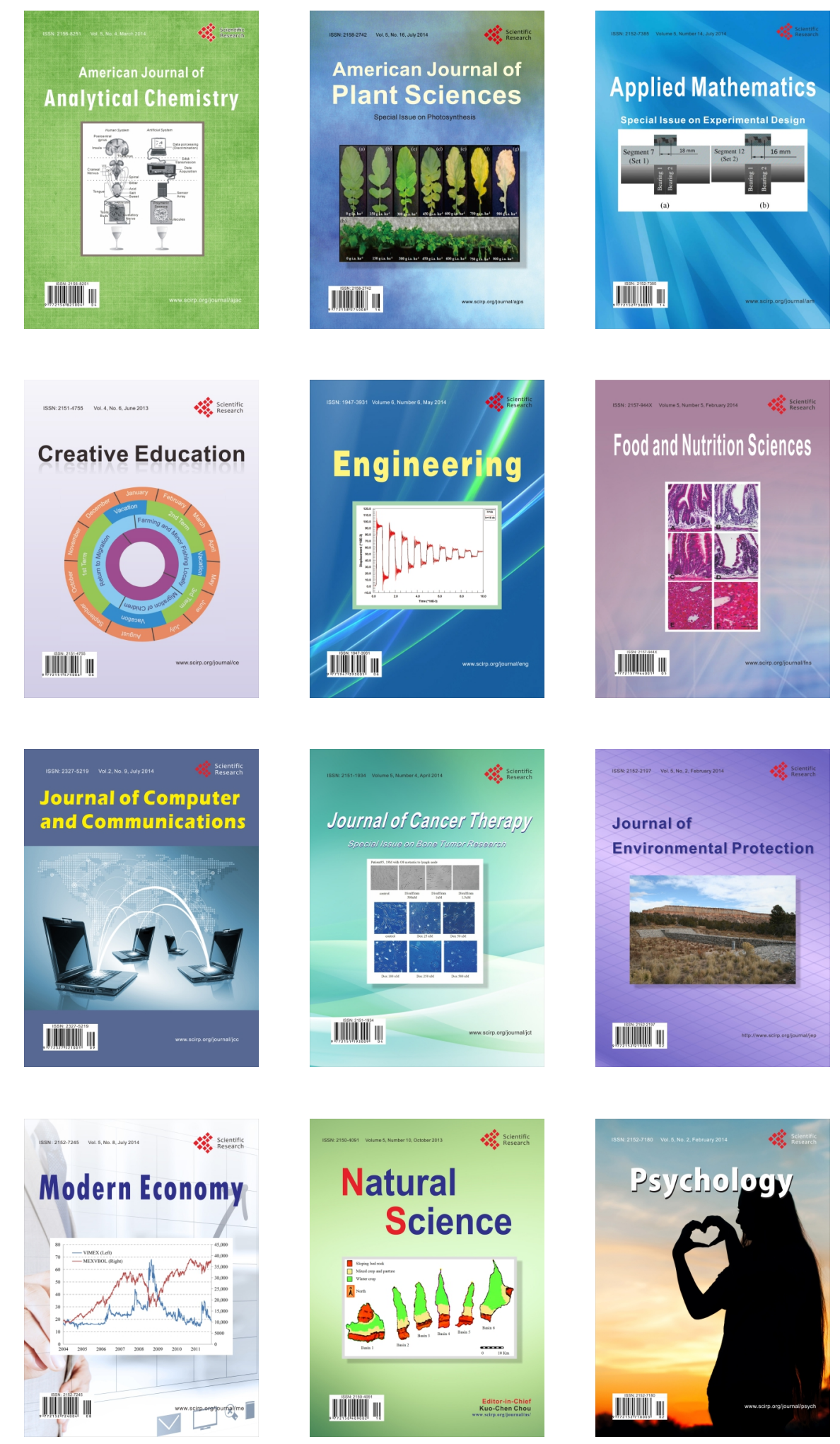